\title{
Uranium isotopes in well water samples as drinking sources in some settlements around the Semipalatinsk Nuclear Test Site, Kazakhstan
}

\author{
Masayoshi Yamamoto · Junpei Tomita - Aya Sakaguchi • \\ Yoshihito Ohtsuka - Masaharu Hoshi - Kazbek N. Apsalikov
}

Received: 17 September 2009/Published online: 18 March 2010

(c) The Author(s) 2010. This article is published with open access at Springerlink.com

\begin{abstract}
Radiochemical results of $U$ isotopes $\left({ }^{234} \mathrm{U}\right.$, ${ }^{235} \mathrm{U}$ and ${ }^{238} \mathrm{U}$ ) and their activity ratios are reported for well waters as local sources of drinking waters collected from the ten settlements around the Semipalatinsk Nuclear Test Site (SNTS), Kazakhstan. The results show that ${ }^{238} \mathrm{U}$ varies widely from 3.6 to $356 \mathrm{mBq} / \mathrm{L}(0.3-28.7 \mu \mathrm{g} / \mathrm{L})$, with a factor of about 100 . The ${ }^{238} \mathrm{U}$ concentrations in some water samples from Dolon, Tailan, Sarzhal and Karaul settlements are comparable to or higher than the World Health Organization's restrictive proposed guideline of $15 \mu \mathrm{g}$ (U)/L. The ${ }^{234} \mathrm{U} /{ }^{238} \mathrm{U}$ activity ratios in the measured water samples are higher than 1 , and vary between 1.1 and 7.9 , being
\end{abstract}

M. Yamamoto $(\bowtie) \cdot$ J. Tomita

Low Level Radioactivity Laboratory, K-INET,

Kanazawa University, Wake, Nomi-shi, Ishikawa 923-1224,

Japan

e-mail: pluto@1lrl.ku-unet.ocn.ne.jp

\section{A. Sakaguchi}

Faculty of Science, Hiroshima University, Kagamiyama, Higashi-Hiroshima, Hiroshima 739-8526, Japan

\section{Y. Ohtsuka}

Institute of Environmental Sciences, Rokkasho-mura,

Aomori 039-3212, Japan

\section{Hoshi}

International Radiation Information Center,

Research Institute for Radiation Biology and Medicine,

Hiroshima University, Hiroshima 734-5883, Japan

K. N. Apsalikov

Kazakh Scientific Research Institute for Radiation Medicine and Ecology, Semipalatinsk, The Kazakhstan Republic mostly from 1.5 to 3 . The measured ${ }^{235} \mathrm{U} /{ }^{238} \mathrm{U}$ activity ratios are around 0.046 , indicating that $U$ in these well waters is of natural origin. It is probable that the elevated concentration of ${ }^{238} \mathrm{U}$ found in some settlements around the SNTS is not due to the close-in fallout from nuclear explosions at the SNTS, but rather to the intensive weathering of rocks including $U$ there. The calculated effective doses to adults resulting from consumption of the investigated waters are in the range $1.0-18.7 \mu \mathrm{Sv} / \mathrm{y}$. Those doses are lower than WHO and IAEA reference value $(100 \mu \mathrm{Sv} / \mathrm{y})$ for drinking water.

Keywords Semipalatinsk nuclear test site - Kazakhstan · Well waters · Uranium isotopes - Annual effective dose

\section{Introduction}

Over a period of 40 years from 1949 to 1989, the former Union of Soviet Socialistic Republics (USSR) conducted more than 450 nuclear explosions at the Semipalatinsk Nuclear Test Site (SNTS), Kazakhstan; 26 of them were above ground, 87 in the atmosphere and 346 underground [1, 2]. Considerable efforts have been devoted to investigate the consequences of radiation exposures to the residents living in the area, particularly in villages contaminated heavily by fallout of the radioactive cloud [1-3].

We have also investigated the present situation of radioecology in and around the SNTS since 1994, and measured long-lived radionuclides ${ }^{137} \mathrm{Cs}$ and $\mathrm{Pu}$ isotopes in large number of soil samples from various areas [4-7]. From these measurements, settlements around the SNTS we visited were found to be contaminated by ${ }^{239,240} \mathrm{Pu}$ with levels from several to a few hundred times higher than those $\left(40-120 \mathrm{~Bq} / \mathrm{m}^{2}\right.$ ) for global fallout observed in Japan, while ${ }^{137} \mathrm{Cs}$ contamination is not so high [8]. Furthermore, 
as for an external radiation dose in the air, it has been gradually clarified that residents of Dolon, where is well known to have been highly contaminated by radioactive fallout due to the first USSR nuclear detonation on 29 August 1949, received around 0.5 Gy [9].

On the other hand, information concerning internal doses experienced by village residents is still very limited around the SNTS. Recently, Tanaka et al. [10] reported that frequencies of unstable-type chromosome aberrations and micronucleus in lymphocytes were higher in residents of contaminated areas such as Dolon, Sarzhal and Kainar than those of the non-contaminated area. They point out that such a higher incidence may be caused mainly by internal exposure, although factors such as age, habitation, smoking, drinking water, medical exposure, life style and so on must be further considered in the interpretation of data from contaminated area.

To serve as an aid to resolve such problem, the present work was aimed at clarifying the present situation of radionuclide levels in well waters as local sources of drinking waters. Among naturally occurring radionuclides, uranium belongs to the most chemical and radiological toxicity of elements for human. Here, we report the present $\mathrm{U}$ isotope $\left({ }^{234} \mathrm{U},{ }^{235} \mathrm{U}\right.$ and $\left.{ }^{238} \mathrm{U}\right)$ levels in well waters collected mainly from the settlements around the SNTS and the associated annual effective doses to adults resulting from consumption of the investigated waters.

\section{Experimental}

\section{Samples}

The settlements where well waters were collected are shown in Fig. 1. These areas are semiarid plains with a low mean annual precipitation $(200-300 \mathrm{~mm})$. Total of 35 well water samples was collected from the contaminated settlements such as Dolon, Sarzhal and Karaul around the SNTS. The $\mathrm{pH}$ measurement in the water was carried out on a potable $\mathrm{pH}$ meter (Model-D-24, Horiba Ltd.) that was calibrated in situ before each set of measurement. The samples were taken in two $200 \mathrm{~mL}$ polyethylene bottles without filtration. In addition, about $100 \mathrm{~mL}$ of water was collected in light-tight glass bottle for measuring alkalinity; diluted mercuric chloride solution was added to the bottle to prevent decomposition of dissolved organic matter and then the bottle was tightly sealed. For comparison, river surface water sample was also collected from the Irtysh River, which is the largest one among them and flows into the Ob River after leaving this area.
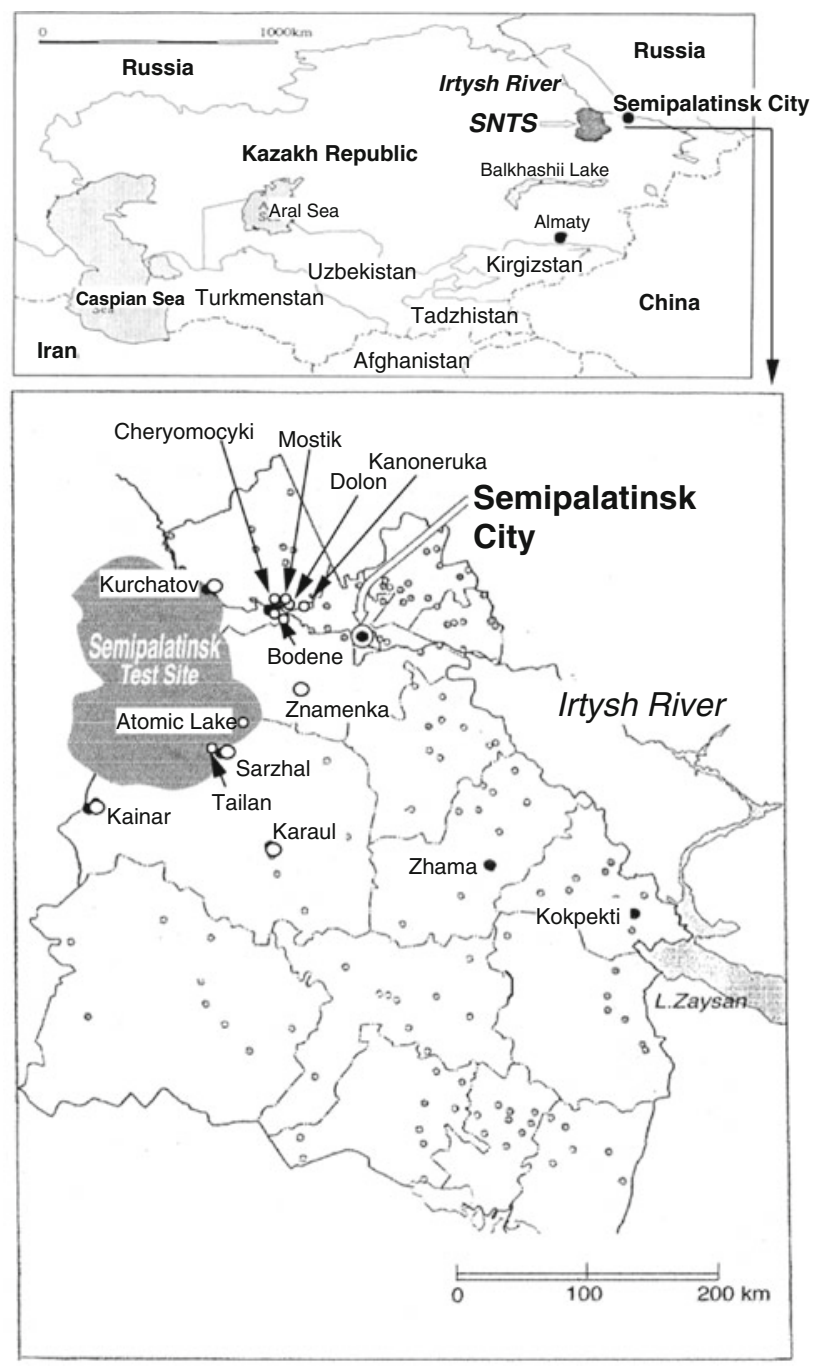

Fig. 1 Map showing sampling locations of well waters around Semipalatinsk Nuclear Test Site, Kazakhstan

\section{Measurement of uranium}

Uranium isotopes were determined by $\alpha$-particle spectrometry after radiochemical separation [11]. The sample water was at first acidified to less than $\mathrm{pH} 1$ by adding a small amount of $\mathrm{HNO}_{3}$. After shaking and standing for overnight, the water was transferred into a $500 \mathrm{~mL}$ beaker with the addition of known amount of ${ }^{232} \mathrm{U}$ as a yield tracer, and evaporated to dryness. The obtained residue was dissolved in $10 \mathrm{M} \mathrm{HCl}$ and the solution was passed through an anion-exchange resin column (Dowex $1 \times 8$ of 100 200 mesh, $\mathrm{Cl}^{-}$form, $\left.0.8 \mathrm{~cm}^{\phi} \times 5 \mathrm{~cm}\right)$. The column was washed with a small amount of $8 \mathrm{M} \mathrm{HNO}_{3}$ to remove adsorbed iron and then by a sufficient amount of $10 \mathrm{M} \mathrm{HCl}$ to remove most of the other elements. Uranium was eluted from the column with $2 \mathrm{M} \mathrm{HCl}$ and the solution was evaporated to dryness. The separated $\mathrm{U}$ was electroplated 
onto a polished stainless steel disc $\left(2 \mathrm{~cm}^{\phi}\right)$, and its activity was measured by $\alpha$-particle spectrometer with measuring time of 3-4 days (Tennelec TC256 spectrometer coupled to a $1 \mathrm{k}$-channel pulse height analyzer). The counting efficiency is about $30 \%$ and the lowest limit of detection is about $0.2 \mathrm{mBq}$ for ${ }^{238} \mathrm{U}$.

Analysis of major chemical compositions

Major dissolved ions $\left(\mathrm{Na}^{+}, \mathrm{K}^{+}, \mathrm{Mg}^{2+}, \mathrm{Ca}^{2+}, \mathrm{Cl}^{-}, \mathrm{NO}_{3}{ }^{-}\right.$ and $\mathrm{SO}_{4}{ }^{2-}$ ) of water samples were determined by ion chromatograph (Dionex ICS-1000). The alkalinity was measured by titration method with $0.1 \mathrm{M} \mathrm{HCl}$ down to $\mathrm{pH}$ $4.8[12]$.

\section{Results and discussion}

\section{Chemical composition}

The chemical composition of 35 investigated waters is listed in Table 1. The $\mathrm{pH}$ of water samples ranges from 7.0 to 8.1 , and is mostly neutral. The cation/anion balance $\left(\left(\Sigma_{\text {cation }}-\Sigma_{\text {anion }}\right) /\left(\Sigma_{\text {cation }}+\Sigma_{\text {anion }}\right)\right.$ in $\left.\mathrm{meq} / \mathrm{L}\right)$ for most of samples measured is smaller than $5 \%$, although some samples have values over $10 \%$. Total dissolved salt (TDS) concentrations are in the range $189-936 \mathrm{mg} / \mathrm{L}$. As a whole, the TDS seems to be higher in Dolon, Mostik, Budene, Znamenka, Salzhal and Karaul than in other settlements. Those water samples contain large amounts of $\mathrm{Na}^{+}, \mathrm{Ca}^{2+}$, $\mathrm{Mg}^{2+}, \mathrm{HCO}_{3}{ }^{-}$and $\mathrm{SO}_{4}{ }^{2-}$.

\section{Uranium levels and isotopic ratios}

The result of the uranium analysis of well water samples is summarized in Table 2, together with those of river water samples from the Irtysh River. It is apparent from Table 2 that concentrations of ${ }^{238} \mathrm{U}$ in the investigated waters vary in a wide range $3.6-356 \mathrm{mBq} / \mathrm{L}(0.3-28.7 \mu \mathrm{g} / \mathrm{L})$, with a factor of about 100 . The lowest concentration $(3.6 \mathrm{mBq} / \mathrm{L})$ of ${ }^{238} \mathrm{U}$ was detected in the well water from Kainar and the highest concentration $(356 \mathrm{mBq} / \mathrm{L})$ of ${ }^{238} \mathrm{U}$ was observed in the well water samples from Karaul. In Dolon and Karaul, the ${ }^{238} \mathrm{U}$ contents change widely even within the area of each settlement. For waters from other settlements, the concentrations of ${ }^{238} \mathrm{U}$ do not change largely. Such variation of ${ }^{238} \mathrm{U}$ concentrations may be connected with the different local, geological and hydrological conditions of the original places of the investigated waters, although the ${ }^{238} \mathrm{U}$ levels seem to increase with increasing mineralization as a whole. Literature values of ${ }^{238} \mathrm{U}$ in freshwater have been reported in the range $0.002-5 \mu \mathrm{g} / \mathrm{L}$, and the median was $0.4 \mu \mathrm{g} / \mathrm{L}$ [13]. Global means, 0.04 and $2.0 \mu \mathrm{g} / \mathrm{L}$, were reported [14]. The ${ }^{238} \mathrm{U}$ contents found here are several to several tens of times higher than the reported values. Kawabata et al. [15, 16] have also observed similarly high ${ }^{238} \mathrm{U}$ concentrations for well water samples collected from some areas in Kazakhstan and Uzbekistan. It is worth noting that the ${ }^{238} \mathrm{U}$ concentrations in some well samples from Dolon, Tailan, Sarzhal and Karaul settlements are comparable to or higher than the World Health Organization's restrictive proposed guideline of $15 \mu \mathrm{g}(\mathrm{U}) / \mathrm{L}$ [17]. Most of the measured ${ }^{234} \mathrm{U} /{ }^{238} \mathrm{U}$ activity ratios are higher than 1 , and vary from 1.5 to 7.9 , with most from 1.5 to 3 . Those higher ratios of ${ }^{234} \mathrm{U} /{ }^{238} \mathrm{U}$ may be explained by preferential leaching of ${ }^{234} \mathrm{U}$ due to the $\alpha$-recoil effect $[11,18]$. No clear relationship is observed between ${ }^{238} \mathrm{U}$ concentration and ${ }^{234} \mathrm{U} /{ }^{238} \mathrm{U}$ activity ratio. On the other hand, all of the measured ${ }^{235} \mathrm{U} /{ }^{238} \mathrm{U}$ activity ratios show the value of around 0.046 with a relatively large counting error of about $10 \%$. It is probable that the elevated concentration of ${ }^{238} \mathrm{U}$ found in some settlements around the SNTS is not due to the close-in fallout from nuclear explosions at the SNTS, but rather to the intensive weathering of rocks including $\mathrm{U}$ there.

The ${ }^{238} \mathrm{U}$ concentrations for river water samples collected from the Irtysh River are $31-37 \mathrm{mBq} / \mathrm{L}(2.5-3.0 \mu \mathrm{g} /$ $\mathrm{L})$. The levels in the Irtysh River are close to the values in well water samples from Mostik and Cheryomocyki. The ${ }^{234} \mathrm{U} /{ }^{238} \mathrm{U}$ activity ratios $(1.7-1.8)$ are nearly the same as those found at settlements around the Irtysh River.

\section{Radiological annual dose}

Assuming that a man drinks $2 \mathrm{~L}$ of water per day, the annual effective doses $(D)$ resulting from consumption of the investigated waters can be calculated using the following formula:

$D(\mu \mathrm{Sv} / \mathrm{y})=\sum I i \cdot F i \cdot 365$

where $I i$ is the concentration of the given $\mathrm{U}$ isotopes (Bq/ day), and geometric mean values of ${ }^{238} \mathrm{U}$ and ${ }^{234} \mathrm{U}$ concentrations were used as representative values for each settlement. The ${ }^{235} \mathrm{U}$ contents were estimated by using the value $(0.046)$ of ${ }^{235} \mathrm{U} /{ }^{238} \mathrm{U}$ activity ratio for natural uranium. The values of $F i$ are the ingestion dose coefficients (dose equivalent per intake of unit activity, $\mathrm{Sv} / \mathrm{Bq}$ ) reported by the International Commission on Radiological Protection [19]; $4.4 \times 10^{-8}$ for ${ }^{238} \mathrm{U}, 4.9 \times 10^{-8}$ for ${ }^{234} \mathrm{U}$ and $4.9 \times 10^{-8}$ for ${ }^{235} \mathrm{U}$. In this case, fractional transfer to blood is assumed to be 0.02 for all uranium isotopes. The effective dose for adults caused by ingestion of uranium isotopes of the investigated well waters are presented in Table 3, except the settlements where only one well water sample was measured. The calculated effective doses vary 
Table 1 Chemical composition of the investigated well and river waters

\begin{tabular}{|c|c|c|c|c|c|c|c|c|c|c|c|c|}
\hline \multirow[t]{2}{*}{ Settlement } & \multirow[t]{2}{*}{ Sampling date } & \multicolumn{10}{|c|}{ Ion concentration $(\mathrm{mg} / \mathrm{L})$} & \multirow[t]{2}{*}{ Ion balance $(\%)^{\mathrm{a}}$} \\
\hline & & $\mathrm{pH}$ & $\mathrm{Na}$ & $\mathrm{K}$ & $\mathrm{Mg}$ & $\mathrm{Ca}$ & $\mathrm{Cl}$ & $\mathrm{NO}_{3}$ & $\mathrm{SO}_{4}$ & $\mathrm{HCO}_{3}$ & TDS & \\
\hline \multicolumn{13}{|c|}{ Kanoneruka } \\
\hline $00 Y 71$ & 08.11 .00 & 8.1 & 4.77 & n.d. & 6.7 & 53.23 & 51.1 & 0.75 & 38.1 & 73 & 228 & -0.4 \\
\hline \multicolumn{13}{|l|}{ Dolon } \\
\hline 05D1 & 09.20 .05 & 7.7 & 93.6 & 19.3 & 24.2 & 62.7 & 33.9 & 71.2 & 114 & 260 & 679 & 5.1 \\
\hline $05 \mathrm{D} 2$ & 09.20 .05 & 7.4 & 120 & 4.0 & 28.4 & 76.7 & 48.6 & 114 & 132 & 293 & 817 & 3.2 \\
\hline 04D1 & 11.11 .04 & 7.6 & 92.7 & 4.6 & 21.8 & 66.0 & 39.7 & 55.7 & 116 & 273 & 670 & 1.7 \\
\hline 04D2 & 11.11.04 & 7.2 & 116 & 3.7 & 26.9 & 81.7 & 66.0 & 104 & 138 & 236 & 773 & 5.2 \\
\hline 04D3 & 11.11 .04 & 7.2 & 93.1 & 17.3 & 22.9 & 61.3 & 46.5 & 70.2 & 119 & 269 & 699 & 0.5 \\
\hline 04D4 & 11.11 .04 & 7.4 & 81.5 & 2.7 & 17.5 & 51.0 & 28.5 & 48.8 & 97.1 & 242 & 569 & 0.0 \\
\hline 04D5 & 11.11 .04 & 7.5 & 73.6 & 4.0 & 16.7 & 49.7 & 19.9 & 10.3 & 65.2 & 301 & 541 & 0.9 \\
\hline 00D1 & 08.11 .00 & 7.4 & 61.5 & n.d. & 23.2 & 107 & 100 & 11.5 & 129 & 266 & 699 & -0.8 \\
\hline 00D2 & 08.11 .00 & 7.4 & 134 & n.d. & 30.9 & 121 & 94.1 & 15.5 & 253 & 294 & 942 & 5.2 \\
\hline \multicolumn{13}{|l|}{ Mostik } \\
\hline Y69 & 08.12 .04 & 7.8 & 14.3 & n.d. & 17.4 & 122 & 95.2 & 17.4 & 62.4 & 199 & 528 & 4.2 \\
\hline \multicolumn{13}{|c|}{ Cheryomocyki } \\
\hline 03CH1 & 10.20 .03 & 7.4 & 14.3 & 0.3 & 10.8 & 21.2 & 7.1 & 5.0 & 17.2 & 113 & 189 & 1.8 \\
\hline $03 \mathrm{CH} 2$ & 10.20 .03 & 7.5 & 37.0 & 29.5 & 21.5 & 38.3 & 34.7 & 25.6 & 48.2 & 129 & 363 & 14.6 \\
\hline $03 \mathrm{CH} 3$ & 10.20 .03 & 7.5 & 20.8 & 6.3 & 18.9 & 37.2 & 15.9 & 17.1 & 29.5 & 117 & 262 & 15.8 \\
\hline 03CH4 & 10.20 .03 & 7.6 & 29.1 & 6.5 & 12.1 & 22.9 & 11.1 & 5.3 & 21.3 & 121 & 229 & 11.8 \\
\hline \multicolumn{13}{|l|}{ Bodene } \\
\hline 03BW1 & 10.22 .03 & 7.5 & 201 & 1.9 & 61.1 & 47.6 & 111 & 39.5 & 211 & 174 & 847 & 19.0 \\
\hline 03BW2 & 10.22 .03 & 7.9 & 231 & 1.3 & 38.0 & 30.0 & 121 & 13.0 & 261 & 180 & 874 & 10.1 \\
\hline 03BW3 & 10.22 .03 & 8.1 & 219 & 1.4 & 38.0 & 19.1 & 109 & 7.2 & 280 & 176 & 851 & 6.8 \\
\hline \multicolumn{13}{|l|}{ Znamenka } \\
\hline $05 Z 1$ & 09.22 .05 & 7.0 & 111 & 1.4 & 37.5 & 41.7 & 50.4 & 106 & 130 & 208 & 686 & 4.1 \\
\hline \multicolumn{13}{|l|}{ Tailan } \\
\hline W-7 & 10.10 .99 & n.a. & 226 & 8.8 & 35.7 & 130 & 118 & n.d. & 399 & n.a. & & \\
\hline \multicolumn{13}{|l|}{ Sarzhal } \\
\hline $05 \mathrm{~S} 1$ & 09.22 .05 & 7.6 & 114 & 2.4 & 29.9 & 70.3 & 59.2 & 18.7 & 228 & 214 & 736 & 3.6 \\
\hline $05 \mathrm{~S} 2$ & 09.22 .05 & 7.8 & 117 & 2.3 & 40.7 & 92.9 & 84.6 & 65.5 & 222 & 271 & 896 & 2.4 \\
\hline 99S1 & 10.10 .99 & n.a. & 131 & n.d. & 40.8 & 142 & 102 & 3.5 & 252 & n.a. & & \\
\hline 99S2 & 10.10 .99 & n.a. & 102 & 10.8 & 35.2 & 119 & 72.5 & n.d. & 189 & n.a. & & \\
\hline $95 \mathrm{~S} 1$ & 10.05 .95 & n.a. & 95.5 & 5.3 & 40.1 & 131 & 104 & 36.2 & 203 & n.a. & & \\
\hline $95 \mathrm{~S} 2$ & 10.05 .95 & n.a. & 140 & 5.2 & 58.8 & 147 & 162 & 81.6 & 272 & n.a. & & \\
\hline \multicolumn{13}{|l|}{ Kainar } \\
\hline 99KA1 & 10.11 .99 & n.a. & 16.3 & 4.6 & 7.1 & 73.7 & 10.5 & n.d. & 50.4 & n.a. & & \\
\hline 99KA2 & 10.11 .99 & n.a. & 25.6 & 10.4 & 10.7 & 87.8 & 25.4 & 2.4 & 53.1 & n.a. & & \\
\hline \multicolumn{13}{|l|}{ Karaul } \\
\hline $04 \mathrm{~K} 1$ & 11.12 .04 & 7.9 & 84.3 & 6.1 & 37.6 & 132 & 84.2 & 177 & 198 & 216 & 936 & 2.4 \\
\hline $04 \mathrm{~K} 2$ & 11.12 .04 & 7.7 & 62.9 & 2.3 & 31.4 & 110 & 44.6 & 69.0 & 185 & 262 & 767 & 1.5 \\
\hline $04 \mathrm{~K} 3$ & 11.12 .04 & 8.0 & 23.7 & 2.1 & 16.2 & 76.4 & 9.1 & 7.9 & 111 & 203 & 450 & 1.6 \\
\hline $04 \mathrm{~K} 4$ & 11.12 .04 & 7.2 & 35.7 & 3.2 & 22.3 & 101 & 28.1 & 47.1 & 109 & 223 & 569 & 6.5 \\
\hline $04 \mathrm{~K} 5$ & 11.12 .04 & 7.5 & 30.8 & 2.6 & 20.1 & 86.0 & 16.6 & 18.6 & 114 & 242 & 531 & 1.7 \\
\hline 04K6 & 11.12 .04 & 7.9 & 23.7 & 2.1 & 16.1 & 76.2 & 9.2 & 8.0 & 112 & 210 & 457 & 0.5 \\
\hline 99K1 & 10.10 .99 & n.a. & n.a. & n.a. & n.a. & n.a. & n.a. & n.a. & n.a. & n.a. & & \\
\hline \multicolumn{13}{|l|}{ Irtysh River } \\
\hline 05R1 & 09.20 .05 & 8.0 & 20.0 & 1.5 & 7.3 & 31.9 & 21.2 & 1.3 & 20.7 & 140 & 244 & -4.4 \\
\hline
\end{tabular}


Table 1 continued

\begin{tabular}{|c|c|c|c|c|c|c|c|c|c|c|c|c|}
\hline \multirow[t]{2}{*}{ Settlement } & \multirow[t]{2}{*}{ Sampling date } & \multicolumn{10}{|c|}{ Ion concentration $(\mathrm{mg} / \mathrm{L})$} & \multirow[t]{2}{*}{ Ion balance $(\%)^{\mathrm{a}}$} \\
\hline & & $\mathrm{pH}$ & $\mathrm{Na}$ & $\mathrm{K}$ & $\mathrm{Mg}$ & $\mathrm{Ca}$ & $\mathrm{Cl}$ & $\mathrm{NO}_{3}$ & $\mathrm{SO}_{4}$ & $\mathrm{HCO}_{3}$ & TDS & \\
\hline 04R1 & 08.12 .04 & 8.3 & 11.6 & n.d. & 8.2 & 58.9 & 24.7 & n.d. & 52.0 & 110 & 266 & 6.9 \\
\hline
\end{tabular}

Error shows $1 \sigma$ standard deviation from counting statistics

${ }^{a}(\Sigma$ cation $-\Sigma$ anion $) /(\Sigma$ cation $+\Sigma$ anion $) \times 100$

n.d. not detected, n.a. not analyzed

Table 2 Results of uranium measurements of the investigated well and river waters

\begin{tabular}{|c|c|c|c|c|}
\hline \multirow[t]{2}{*}{ Settlement } & \multicolumn{2}{|c|}{${ }^{238} \mathrm{U}$ concentration } & \multicolumn{2}{|l|}{ Activity ratio } \\
\hline & $(\mathrm{mBq} / \mathrm{L})$ & $(\mu \mathrm{g} / \mathrm{L})$ & ${ }^{234} \mathrm{U} /{ }^{238} \mathrm{U}$ & ${ }^{235} \mathrm{U} /{ }^{238} \mathrm{U}$ \\
\hline \multicolumn{5}{|c|}{ Kanoneruka } \\
\hline $00 Y 71$ & $11.4 \pm 0.7$ & 0.92 & $1.63 \pm 0.12$ & $0.047 \pm 0.008$ \\
\hline \multicolumn{5}{|l|}{ Dolon } \\
\hline 05D1 & $189.9 \pm 6.8$ & 15.3 & $1.63 \pm 0.03$ & $0.044 \pm 0.002$ \\
\hline 05D2 & $157.2 \pm 8.7$ & 12.6 & $1.64 \pm 0.06$ & $0.043 \pm 0.002$ \\
\hline 04D1 & $99.8 \pm 5.0$ & 8.03 & $1.44 \pm 0.05$ & \\
\hline 04D2 & $194.6 \pm 12.1$ & 15.7 & $1.54 \pm 0.06$ & \\
\hline 04D3 & $197.9 \pm 11.4$ & 15.9 & $1.48 \pm 0.05$ & \\
\hline 04D4 & $45.1 \pm 1.4$ & 3.62 & $1.65 \pm 0.05$ & \\
\hline 04D5 & $51.4 \pm 2.8$ & 4.13 & $1.51 \pm 0.07$ & \\
\hline 00D1 & $135.6 \pm 6.3$ & 10.9 & $1.42 \pm 0.06$ & $0.040 \pm 0.005$ \\
\hline 00D2 & $117.1 \pm 5.4$ & 9.42 & $1.36 \pm 0.06$ & $0.048 \pm 0.004$ \\
\hline \multicolumn{5}{|l|}{ Mostik } \\
\hline Y69 & $49.2 \pm 2.2$ & 3.96 & $1.54 \pm 0.07$ & $0.050 \pm 0.010$ \\
\hline \multicolumn{5}{|c|}{ Cheryomocyki } \\
\hline 03CH1 & $42.3 \pm 1.9$ & 3.40 & $1.36 \pm 0.06$ & $0.047 \pm 0.006$ \\
\hline $03 \mathrm{CH} 2$ & $25.1 \pm 0.7$ & 2.02 & $1.44 \pm 0.05$ & \\
\hline $03 \mathrm{CH} 3$ & $22.6 \pm 0.7$ & 1.81 & $1.38 \pm 0.05$ & $0.043 \pm 0.006$ \\
\hline 03CH4 & $28.9 \pm 0.7$ & 2.33 & $1.53 \pm 0.04$ & \\
\hline \multicolumn{5}{|l|}{ Bodene } \\
\hline 03BW1 & $144.3 \pm 4.8$ & 11.6 & $2.93 \pm 0.06$ & $0.048 \pm 0.005$ \\
\hline 03BW2 & $114.2 \pm 4.9$ & 9.19 & $2.98 \pm 0.08$ & $0.043 \pm 0.005$ \\
\hline 03BW3 & $139.9 \pm 5.2$ & 11.2 & $2.67 \pm 0.06$ & $0.049 \pm 0.006$ \\
\hline \multicolumn{5}{|l|}{ Znamenka } \\
\hline $05 Z 1$ & $36.5 \pm 2.5$ & 2.94 & $6.80 \pm 0.38$ & $0.045 \pm 0.005$ \\
\hline \multicolumn{5}{|l|}{ Tailan } \\
\hline $\mathrm{W}-7$ & $274.0 \pm 10.9$ & 22.0 & $1.97 \pm 0.06$ & $0.049 \pm 0.003$ \\
\hline \multicolumn{5}{|l|}{ Sarzhal } \\
\hline $05 \mathrm{~S} 1$ & $144.4 \pm 6.1$ & 11.6 & $2.42 \pm 0.06$ & $0.044 \pm 0.003$ \\
\hline $05 \mathrm{~S} 2$ & $213.9 \pm 12.0$ & 17.2 & $2.41 \pm 0.07$ & $0.043 \pm 0.003$ \\
\hline 99S1 & $206.4 \pm 14.1$ & 16.6 & $2.35 \pm 0.13$ & $0.048 \pm 0.003$ \\
\hline $99 \mathrm{~S} 2$ & $127.8 \pm 6.9$ & 10.3 & $2.19 \pm 0.11$ & $0.052 \pm 0.006$ \\
\hline $95 \mathrm{~S} 1$ & $156.1 \pm 8.3$ & 12.6 & $2.15 \pm 0.10$ & $0.050 \pm 0.006$ \\
\hline $95 \mathrm{~S} 2$ & $172.4 \pm 10.0$ & 13.9 & $2.26 \pm 0.12$ & $0.045 \pm 0.005$ \\
\hline \multicolumn{5}{|l|}{ Kainar } \\
\hline 99KA1 & $3.56 \pm 0.59$ & 0.29 & $7.88 \pm 1.28$ & \\
\hline 99KA2 & $4.14 \pm 0.67$ & 0.33 & $5.51 \pm 0.87$ & \\
\hline
\end{tabular}

Table 2 continued

\begin{tabular}{cccccc}
\hline Settlement & \multicolumn{2}{l}{${ }^{238} \mathrm{U}$ concentration } & & \multicolumn{3}{l}{ Activity ratio } \\
\cline { 2 - 3 } \cline { 5 - 6 } & $(\mathrm{mBq} / \mathrm{L})$ & $(\mu \mathrm{g} / \mathrm{L})$ & & ${ }^{234} \mathrm{U} /{ }^{238} \mathrm{U}$ & ${ }^{235} \mathrm{U} /{ }^{238} \mathrm{U}$ \\
\hline Karaul & & & & & \\
04K1 & $82.8 \pm 4.9$ & 6.66 & & $2.34 \pm 0.10$ & \\
04K2 & $90.8 \pm 6.6$ & 7.30 & & $2.16 \pm 0.11$ & $0.048 \pm 0.005$ \\
04K3 & $52.1 \pm 3.6$ & 4.19 & & $2.53 \pm 0.14$ & \\
04K4 & $116.8 \pm 7.4$ & 9.39 & & $1.51 \pm 0.07$ & $0.045 \pm 0.004$ \\
04K5 & $97.6 \pm 5.1$ & 7.85 & & $1.73 \pm 0.07$ & $0.048 \pm 0.005$ \\
04K6 & $48.6 \pm 2.8$ & 3.91 & & $2.35 \pm 0.11$ & \\
99K1 & $355.6 \pm 23.4$ & 28.6 & & $1.09 \pm 0.06$ & $0.047 \pm 0.009$ \\
Irtysh River & & & & & \\
05R1 & $31.0 \pm 1.3$ & 2.49 & & $1.77 \pm 0.07$ & $0.044 \pm 0.005$ \\
04R1 & $37.0 \pm 1.5$ & 2.98 & $1.65 \pm 0.06$ & \\
\hline
\end{tabular}

Error shows $1 \sigma$ standard deviation from counting statistics

from 1.0 to $18.7 \mu \mathrm{Sv} / \mathrm{y}$. The dose $(18.7 \mu \mathrm{Sv} / \mathrm{y})$ estimated for the adults living in the Sarzhal region is comparable to the value of $16 \mu \mathrm{Sv} / \mathrm{y}$ (range 9-20 $\mu \mathrm{Sv} / \mathrm{y}$ ) reported recently by Vintró et al. [20]. Those doses are lower than WHO and IAEA reference value $(100 \mu \mathrm{Sv} / \mathrm{y})$ for drinking water $[21,22]$.

\section{Conclusion}

The concentrations of ${ }^{238} \mathrm{U}$ in the well water samples from some settlements around the SNTS vary in a wide range $3.6-356 \mathrm{mBq} / \mathrm{L}(0.3-28.7 \mu \mathrm{g} / \mathrm{L})$. The ${ }^{238} \mathrm{U}$ concentrations in some samples from Dolon, Tailan, Sarzhal and Karaul settlements are comparable to or higher than the World Health Organization's restrictive proposed guideline of $15 \mu \mathrm{g}(\mathrm{U}) / \mathrm{L}$. The measured ${ }^{234} \mathrm{U} /{ }^{238} \mathrm{U}$ activity ratios are higher than 1, and are mostly from 1.5 to 3 . The ${ }^{235} \mathrm{U} /{ }^{238} \mathrm{U}$ activity ratios show the value of around 0.046 , indicating that $U$ in the wells is of natural origin. It is probable that the higher ${ }^{238} \mathrm{U}$ concentrations are not due to the close-in fallout from nuclear explosions at the SNTS, but rather to the intensive weathering of rocks including $U$ there. The calculated annual effective doses arising from the ingestion 
Table 3 Annual effective dose to adult arising from U ingestion (consuming $2 \mathrm{~L}$ of water daily) through well water in each settlement

\begin{tabular}{|c|c|c|c|c|c|c|}
\hline \multirow[t]{2}{*}{ Settlement } & \multirow{2}{*}{$\begin{array}{l}\text { Analyzed number } \\
\text { of samples }\end{array}$} & \multirow{2}{*}{$\begin{array}{l}\text { Range } \\
{ }^{238} \mathrm{U}(\mathrm{mBq} / \mathrm{L})\end{array}$} & \multicolumn{3}{|c|}{ Geometric mean } & \multirow{2}{*}{$\begin{array}{l}\text { Effective } \\
\text { dose }(\mathrm{mSv} / \mathrm{y})\end{array}$} \\
\hline & & & ${ }^{238} \mathrm{U}(\mathrm{mBq} / \mathrm{L})$ & ${ }^{234} \mathrm{U}(\mathrm{mBq} / \mathrm{L})$ & ${ }^{235} \mathrm{U}^{\mathrm{a}}(\mathrm{mBq} / \mathrm{L})$ & \\
\hline Dolon & 9 & $45.1-197.9$ & 117.3 & 177.9 & 5.4 & 10.3 \\
\hline Cheryomocyki & 4 & $22.6-42.3$ & 28.9 & 41.1 & 1.3 & 2.4 \\
\hline Bodene & 3 & $114.2-144.3$ & 132.1 & 377.4 & 6.1 & 18.0 \\
\hline Sarzhal & 6 & $127.8-213.9$ & 167.3 & 365.4 & 7.7 & 18.7 \\
\hline Kainar & 2 & $3.56-4.14$ & 3.8 & 25.3 & 0.2 & 1.0 \\
\hline Karaul & 7 & $48.6-355.6$ & 94.6 & 181.9 & 4.4 & 9.8 \\
\hline
\end{tabular}

${ }^{\text {a }}$ Contents of ${ }^{235} \mathrm{U}$ were calculated by using the value $(0.046)$ of ${ }^{235} \mathrm{U} /{ }^{238} \mathrm{U}$ for natural $\mathrm{U}$

of $\mathrm{U}$ isotopes $\left({ }^{234} \mathrm{U},{ }^{235} \mathrm{U}\right.$ and $\left.{ }^{238} \mathrm{U}\right)$ are in the range $1.0-$ $18.7 \mu \mathrm{Sv} / \mathrm{y}$, and are lower than the recommended value of $100 \mu \mathrm{Sv} / \mathrm{y}$ for drinking water.

Acknowledgments We would like to express our gratitude to the research staff of the Kazakh Scientific Research Institute of Radiation Medicine and Ecology for their help with sampling. This work was supported by a Grand-in-Aid (M. Y. and M. H.: 1995-2005) for Scientific Research from the Ministry of Education, Culture, Sports, Science and Technology, Japan.

Open Access This article is distributed under the terms of the Creative Commons Attribution Noncommercial License which permits any noncommercial use, distribution, and reproduction in any medium, provided the original author(s) and source are credited.

\section{References}

1. Gusev BI, Abylkassimova ZN, Apsalikov KN (1977) Radiat Environ Biophys 39:201

2. Gordeev K, Vasilenko I, Lebedev A, Bouville A, Luckyanov N, Simon SL, Shinkarev S, Anspaugh L (2002) Radiat Environ Biophys 41:61

3. Grosche B, Land C, Bauer S, Pivina LM, Abylkassimova ZN, Gusev BI (2002) Radiat Environ Biophys 41:75

4. Yamamoto M, Tsumura A, Katayama Y, Tsukatani T (1996) Radiochim Acta 40:209

5. Yamamoto M, Tsukatani T, Katayama Y (1996) Health Phys $71: 142$

6. Yamamoto M, Hoshi M, Takada J, Sakelbaev AK, Gusev BI (1999) J Radioanal Nucl Chem 242:63

7. Yamamoto M, Hoshi M, Takada J, Sakaguchi A, Apsalikov KN (2004) J Radioanal Nucl Chem 261:19
8. Yamamoto M, Komura K, Sakanoue M (1983) J Radiat Res 24:237

9. Imanaka T, Fukutani S, Yamamoto M, Sakaguchi A, Hoshi M (2006) J Radiat Res 47 Suppl:A121

10. Tanaka K, Iida S, Takeichi N, Chaizhunusova NJ, Gusev BI, Apsalikov KN, Inaba T, Hoshi M (2006) J Radiat Res 47 Suppl:A159

11. Yamamoto M, Sato T, Sasaki K, Hama K, Nakamura T, Komura K (2003) J Radioanal Nucl Chem 255:369

12. Tomita J, Satake H, Sasaki K, Sakaguchi A, Inoue M, Hamajima Y, Yamamoto M (2008) J Hot Spring Sci 58:244 (in Japanese)

13. Bowen HL (1979) In: Environmental chemistry of the elements. Academic press, New York, p 1611

14. United Nations Scientific Committee on the Effects of Atomic Radiation (1988) In: Sources, effects, and risks of ionizing radiation. New York

15. Kawabata Y, Aparin V, Nagai M, Yamamoto M, Shiraishi K, Katayama Y (2008) J Radioanal Nucl Chem 278:459

16. Kawabata Y, Yamamoto M, Aparin V, Ko S, Shiraishi K, Nagai M, Katayama Y (2006) J Radioanal Nucl Chem 270:137

17. Guidelines for drinking water quality, 3rd edn. World Health Organization (WHO), Geneva, Switzerland (2004)

18. Kigoshi K (1971) Science 173:47

19. International Commission of Radiological Protection (1994) Dose coefficient for intake of radionuclides by workers. In: Replacement of ICRP Publication 61. Pergamon Press ICRP Publication 68, Oxford

20. Vintró LL, Mitchell PJ, Omarova A, Burkitbayev M, Jiménez Nápoles H, Priest ND (2009) J Environ Radioact 100:308

21. Guidelines for drinking water quality, Chapter 9, 3rd edn. World Health Organization (WHO), Geneva, Switzerland (2003)

22. Radionuclide content in commodities not requiring regulation for the purposes of radiation protection. In: Draft safety guide DS161. IAEA, Vienna, p 14 (2002) 